\title{
PKM PEMBERDAYAAN KELOMPOK WANITA NELAYAN DESA KALIBURU KECAMATAN SINDUE TOMBUSABORA KABUPATEN DONGGALA SULAWESI TENGAH
}

\author{
Ahsan Mardjudo ${ }^{{ }^{*}}$ dan Asrawaty ${ }^{2}$ \\ ${ }^{1}$ Program Studi Agrobisnis Perikanan, Fakultas Perikanan Universitas Alkhairaat Palu \\ ${ }^{2}$ Program Studi Teknologi Hasil Pertanian Fakultas Pertanian Universitas Alkhairaat Palu \\ Jl. Diponegeoro No. 39 Palu Sulawesi Tengah \\ Email : ahsan.mardjudo@gmail.com
}

\begin{abstract}
ABSTRAK
Tujuan Program Kemitraan Masyarakat (PKM) adalah untuk meningkatkan pengetahuan dan skill kelompok wanita nelayan melalui transformasi teknologi pengolahan dan pengemasan ikan tuna menjadi berbagai macam jenis olahan yang bernilai ekonomis, menciptakan lapangan kerja melalui pengembangan pengelolaan usaha home industry dan peningkatan pendapatan masyarakat melalui penjualan dari hasil pengolahan ikan tuna berupa abon ikan, nugget ikan dan pancake fish. Dalam kegiatan PKM metode yang dikembangkan adalah kegiatan pendidikan dan pelatihan, serta demo pembuatan aneka produk yang berasal bahan baku perikanan. Selain itu menggunakan pendekatan learning by doing melalui kelompok home industri yaitu belajar sambil bekerja/berusaha. Melalui PKM ini akan mengembangkan usaha home industi yang berbasis potensi lokal yang di fokuskan pada pengolahan hasil perikanan. Dengan sentuhan PKM kelompok mitra akan mampu mengembangkan potensi sumberdaya ikan dapat meningkatkan produk yang bernilai ekonomis. Pengembangan pengetahuan, ketrampilan dan penguasaan teknologi khususnya Teknologi Tepat Guna (TTG), masyarakat mampu mengakses potensi yang ada di lingkungan mereka, sehingga dapat menambah pendapatan keluarga menuju masyarakat sejahtera dan mandiri. Adapun realiasi kegiatan adalah terlaksananya pelatihan pengolahan abon ikan, nugget ikan dan pancake fish.
\end{abstract}

Katakunci: Pemberdayaan wanita nelayan, Kaliburu, Sindue Tombusabora

\section{Pendahuluan}

Desa Kaliburu adalah salah satu desa dari 6 desa yang ada di Kecamatan Sindue Tombusabora Kabupaten Donggala. Jumlah penduduk desa ini sebanyak 2.267 yang terdiri dari laki-laki 1.167 dan perempuan 1.100 jiwa, 553 rumahtangga dengan luas 104,64 km (Kecamatan Sindue Tombusabora dalam angka, 2015). Dari 6 desa yang ada di Kecamatan Sindue Tombusabora terdapat 5 desa pantai namun memiliki juga di pengunungan. Penduduk yang bermungkin di pesisir pantai mata pencahariannya sebagainelayan dan yang ada dipengunungan mata pencaharian adalah dibidang pertanian.

Desa Kaliburu merupakan salah satu desa yang komposisi masyarakatnya sebagian besar bekerja sebagai nelayan tradisional, tenaga buruh tangkap ikan. Jenis ikan yang banyak dipasok adalah jenis ikan tuna. Meningkatnya hasil tangkapan ikan tuna berdampak pada masalah pemasaran ikan tuna utamanya harga jual yang relatif lebih murah diterima oleh nelayan. Harga jual ikan tuna sebesar Rp.8000/kg yang seharusnya harga jual sebesar Rp.18.000/kg. Rendahnya harga jual yang diterima oleh nelayan menyebabkan kerugian yang besar. Ketidakberdayaan nelayan secara ekonomi dan pengetahuan nelayan yang rendah terhadap hasil tangkapan ikan tuna tetap dijual meskipun dengan harga yang relatif lebih murah. Permasalahan ketidakberdayaan secara ekonomi sehingga masyarakat pesisir khususnya masyarakat nelayan identik dengan kemiskinan karena ketidakberdayaan masyarakat dalam mengelola sumber daya alam yang tersedia.

Ketidakberdayaan ibu-ibu nelayan dalam mengelola hasil tangkapan yang melimpah, menyebabkan hasil tangkapan tetap dijual dengan harga yang murah. Minimnya kreativitas yang dimiliki oleh ibuibu nelayan disebabkan oleh tingkat 
pendidikan dan pengetahuan yang rendah. Aktivitas yang sering dilakukan oleh ibu-ibu nelayan dalam mengisi waktunya yang luang digunakan pada kegiatan bergosip, mengurus dapur, dan tertutup dengan orang baru. Melalui usulan program PKM 2019 diharapkan dapat merubah sikap dan perilaku ibu-ibu nelayan menjadi manusia yang kreatif, terbuka dan mampu berbicara di depan umum. Minimnya aktivitas yang bermanfaat yang dilakukan sehingga tak dapat membantu perekonomian keluarga.

Menurut Muhammad (2012), pemberdayaan individu dan keluarga pada hakekatnya adalah upaya menciptaan suatu lingkungan yang mampu membangkitkan keyakinan diri, memberi peluang dan motivasi agar setiap individu dalam rumahtangga mampu meningkatkan kemampuan dirinya meraih atau mengakses sumberdaya sosial dan ekonomi bagi pengembangan dan kemajuan kehidupannya.

Berdasarkan hasil survey yang kami lakukan, maka untuk mengatasi permasalahan yang dihadapi oleh masyarakat pesisir yang berprofesi sebagai nelayan, maka akan dilakukan kegiatan pengabdian pada masyarakat melalui pendampingan teknis dari Universitas Alkhairaat Palu melalui program hibah PKM. Pelaksanaan pengabdian akan dilakukan serangkaian kegiatan diantaranya sosialisasi, pelatihan dan pendampingan. Melalui program PKM ini akan menambah pengetahuan serta menciptakan kreativitas istri-istri para nelayan dalam mengelola ikan tuna. Adapun analisis kelayakan usaha skala rumah tangga dalam mengolah ikan tuna menjadi abon ikan sebesar $10 \mathrm{~kg}$ perminggunya dengan rendemen sebesar $40 \%$. Total biaya produksi sebesar Rp.150.000 dengan produksi abon ikan sebesar $6 \mathrm{~kg}$ per minggu. Abon ikan dijual dengan harga Rp.70.000 kg, dengan demikian total penghasilan rumah tangga sebesar Rp. 420.000 per minggu dikurangi dengan biaya produksi sebesar Rp.150.000, maka keuntungan yang bisa diperoleh setiap minggunya sebesar Rp. 270.000.Selain pengolahan pascapanen lebih lanjut, dengan bertambahnya kreativitas istri-istri nelayan akan menciptakan lapangan kerja baru dan membantu menambah pendapatan ekonomi keluarga. Dengan pendampingan teknis dari Universitas Alkhairaat Palu diharapkan tercipta kemandirian melalui peningkatan pendapatan secara berkelanjutan.

Menciptakan pendapatan masyarakat nelayan secara berkelanjutan dapat dilakukan melalui penanganan pada bagian pasca panen yang merupakan tahap akhir dari rangkaian kegiatan nelayan. Ada berbagai bentuk pengolahan produk hasil tangkapan nelayan yang sudah dikenal, misalnya pengeringan, pengasapan, penggaraman, pemindangan, dan fermentasi. Salah satu bentuk produk olahan dengan proses pengolahan adalah abon ikan dan bakso ikan. Abon Ikan dan Bakso Ikan merupakan bentuk makanan semi basah yang biasanya terbuat dari daging atau ikan.

Produk abon ikan telah dikenal masyarakat Indonesia sejak lama.rasa dan aromanya yang khas serta sesuai dengan selera masyarakat kita menyebabkan produk dendeng digemari oleh masyarakat secara luas. Pembuatan abon ikan dan bakso ikan pada umumnya masih dilakukan secara tradisional proses produksinya tidak rumit, bahan baku mudah diperoleh, dan alat-alat yang digunakan cukup sederhana. Dengan demikian, pembuatan abon ikan dan bakso ikan dapat diusahakan dalam skala rumah tangga atau industri kecil. Teknologi produksi yang mudah dan prospek pasar yang cukup cerah membuat usaha pembuatan dendeng menjadi salah satu alternatif usaha yang cukup menjanjikan.

Melalui usulan program PKM 2019 diharapkan terjadi perubahan perilaku menuju peningkatan pendapatan tinggi dan tingkat kesejahteraan. Distribusi hasil olahan di pasar swalayan biasanya menghendaki mutu abon ikan yang baik. Abon ikan yang memiliki mutu baik dapat juga menjadi komoditas ekspor. Ada beberapa faktor penting tentang keunggulan kompetitif yang kita miliki untuk mengalahkan pesaing yaitu dengan meningkatkan mutu seperti bahan baku yang segar, tehnik pengolahan yang tepat, faktor kebersihan terjamin/higienis, 
komposisi bumbu yang tepat, dan yang terutama tidak menggunakan bahan pengawet kimia yang membahayakan konsumen. Berdasarkan beberapa uraian tersebut di atas, maka disusunlah proposal pengabdian ini tentang PKM Pemberdayaan Kelompok Wanita Nelayan Desa Kaliburu dalam Mengelola Ikan Tuna atau jenis ikan lainnya Menjadi Usaha Rumahtangga.

Ada beberapa masalah yang dihadapi masyarakat sehingga tidak dapat mengakses potensi lokal atau tidak berdaya untuk mengolah potensi lokal menjadi bernilai ekonomis. Secara rinci permasalahan yaitu sebagai berikut:

1. Rendahnya keterlibatan masyarakat dalam berbagai kegiatan dalam pembangunan di desanya.

2. Tingkat kesejahteraan masyarakat yang masih rendah;

3. Kurangnya pengetahuan dan ketrampilan masyarakat

4. Kurangnya penguasaan teknologi yang berbasis TTG

5. Rendahnya kreativitas masyarakat

6. Kurangnya kelompok home industri

7. Kurang mendapat pendampingan secara khusus.

\section{Solusi Permasalahan}

Bertolak dari permasalahan di atas maka team pengusul menyampaikan beberapa usulan untuk penyelesaian masalah yang dihadapi masyarakat desa Kaliburu Kecamatan Sindue Tombusabora melalui kegiatan PKM ini antara lain yaitu sebagai berikut:

\section{Melibatkan peran serta masayarakat}

Melibatkan peran serta masayarakat dalam segala bentuk kegiatan program PKM, baik dalam pengambilan keputusan maupun pelaksanaan kegiatan. Hal ini diperuntukkan untuk keberlanjutan program sehingga timbul rasa memiliki dari masyarakat sehingga aprogram ini dipelihara. Jadi wanita nelayan dapat membentuk kelompok dalam pengembangan ekonomi kreatif sesuai potensi yang yang dimiliki desa sebagai sasaran program PKM.

\section{Pengembangan kewirausahaan}

Program PKM dapat mengembangkan kelompok ekonomi kreatif melalui home industri sehingga terbentuk wanita-wanita nelayan yang berjiwa wirausaha oleh sebab itu dalam program ini dikembangkan program penyuluhan kewirausahaan.

\section{Pendidikan dan Pelatihan}

Pendidikan dan pelatiha dilakukan sebagai upaya peningkatan sumber daya manusia (SDM), sehingga dapat mengakses potensi lokal menjadi produk yang bernilai ekonomis. Adapun bentuk pelatihan yang dikembangkan dalam program PKM yaitu sebagai berikut:

1) Pendidikan dan pelatihan teknis pembuatan produk

Kegiatan ini merupakan prosedur pembutan produk olahan hasil perikanan meliputi: Pembuatan Abon dan Bakso Ikan.

2) Pendidikan dan pelatihan non teknis Hal ini lebih menekankan manajemen kewirausahaan yang meliputi:

- Penguatan kelembagaan kelompok

- Administrasi keuangan (pembukuan) kelompok ekonomi kreatif

- Strategi pemasaran produk

\section{Pendampingan pasca pelatihan}

Pembuatan produk pengolahan hasil perikanan akan dilaksanakan bagi kelompok wanita nelayan yang sudah terbentuk. Hasil dari olahan ini dari kelompok wanita nelayan merupakan produk yang cikal bakal untuk dipasarkan.

- Pengemasan produk

Pengemasan Produk sangat menentukan dalam proses pemasaran, oleh sebab itu pengemasan merupakan daya tarik dari produk, sehingga perlu didesain sedemikian rupa untuk daya tarik pembeli produk

- Pemasaran produk

Produk yang sudah dikemas dengan baik siap untuk dipasarkan sesuai sekmen pasar yang direncanakan. Sekmen pasar yang direncanakan ada 3 
yaitu; pemasaran ditingkat pasar tradisional, di pasar swalayan misalnya di BNS, Matahari dan lain-lain, dan secara on line melalui internet.

- Manajemen kelompok

Dalam kegiatan ini ada beberapa kegiatan yang dikembangkan yaitu sebagai berikut;

$>$ Aplikasi administrasi kelompok binaan yang meliputi rencana kerja dan pembuatan SK kelompok dan lain-lain.

Aplikasi pembukuan hasil penjualan produk artinya penjualan produk dimasukkan dalam pembukuan dan lain-lain.

\section{Metode Pelaksanaan}

\section{Waktu dan Tempat}

Kegiatan PKM ini akan dilaksanakan di dua kelompok mitra di Desa Kaliburu Kecamatan Sindue Tombusabora Kabupaten Donggala. kedua kelompok ini merupakan kelompok wanita nelayan dalam memanfaatkan hasil tangkapan khususnya ikan tuna diolah dengan berbagai macam hasil olahan. Kegiatan ini akan dilaksanakan selama 8 bulan yang dimulai pada Bulan Maret sampai September 2019.

\section{Metode Kegiatan}

Pemberdayaan masyarakat nelayan khususnya wanita nelayan dapat dilakukan secara integrasi melalui peningkatan sumberdaya manusia, pengolahan sumberdaya alam, lingkungan dan pembentukan usaha. Dalam menangani berbagai masalah yang dihadapi masyarakat nelayan dapat dipecahkan dengan menerapkan strategi pelaksanaan kegiatan PKM terbagi dalam beberapa tahap sebagai berikut:

\section{Tahap Pelaksanaan}

Pendekatan yang akan diterapkan dalam mendukung realisasi tahap pelaksanaan kegiatan pengabdian PKM sebagai berikut:

\section{a. Tahapan Sosialisasi}

Pelaksanaan kegiatan PKM ini akan diawali dengan kegiatan sosialisasi yang bertujuan untuk memberikan informasi tentang program PKM serta membuka wawasan dan meningkatkan pengetahuan, pemahaman dan penyamaan persepsi wanita nelayan melalui pemanfaatan sumber daya alam hasil perikanan secara optimal khususnya ikan tuna.

\section{b. Tahapan Pelatihan}

Peningkatan kemampuan dan keterampilan sumber daya anggota kelompok wanita nelayan dalam mengolah, meningkatkan produksi dan manajemen usaha, maka akan dilakukan kegiatan melalui media penyuluhan dan pelatihan serta demo pembuatan produk

\section{Hasil dan Pembahasan \\ Tahap Sosialisasi}

Sosialisasi PKM kepada pemerintah desa setempat dan ketua kelompok tentang rencana kegiatan serta waktu pelaksanaan kegiatan pelatihan pembuatan abon ikan, nugget ikan dan pancake fish.

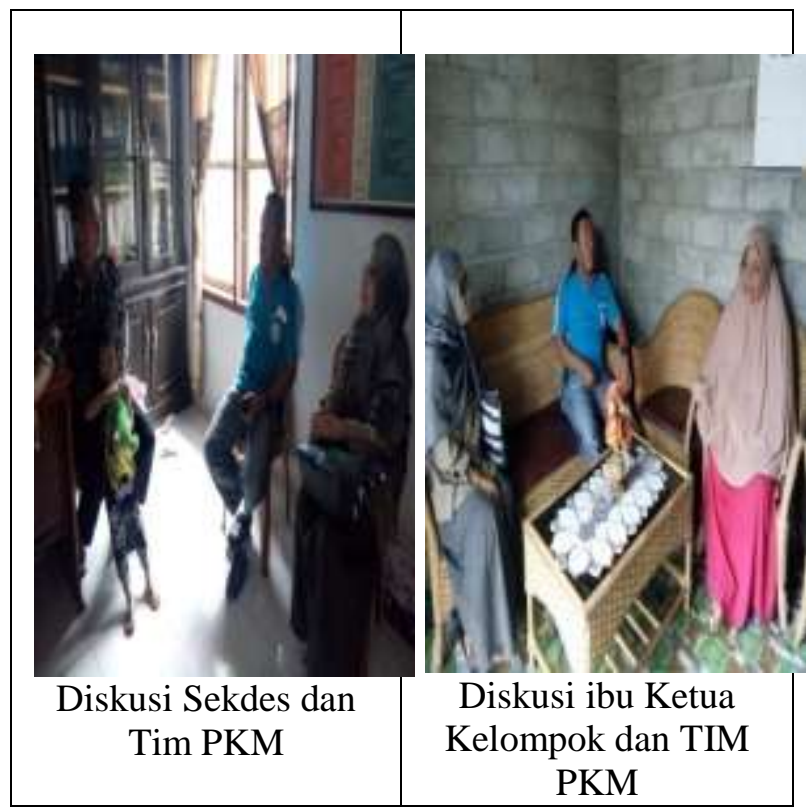

Gambar 1. Kegiatan Sosialisasi di Desa

\section{Tahap Pelaksananaan Acara Pembukaan}

Pelaksanaan kegiatan PKM sesuai kesepakatan dengan pemerintah desa dan ketua kelompok pada tanggal 19 Juli 2019 
mulai jam 08.00 s/d 17.00 WITA. Dengan agenda acara: 1. Pembukaan terdiri dari Sambutan Ketua Tim PKM dan Sambutan Kepala Desa Kaliburu sekaligus membuka acara kegiatan PKM. 2. Penyerahan atribut dan alat-alat yang akan digunakan dalam kegiatan. 3. Penjelasan teknis oleh narasumber tentang materi pelatihan pengolahan hasil perikanan pada Gambar 2.

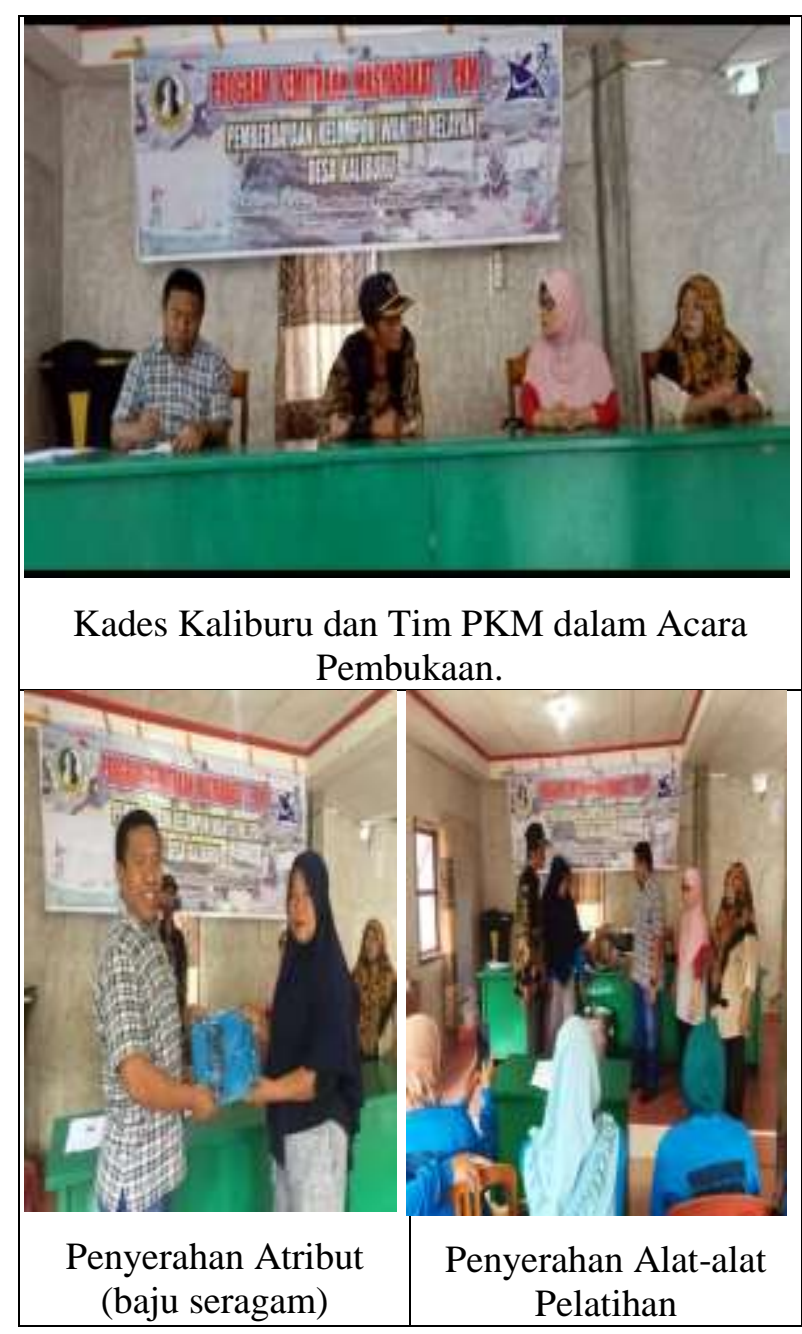

Gambar 2. Kegiatan PKM di Desa Kaliburu

Kegiatan PKM di Desa Kaliburu di awali dengan acara pembukaan secara resmi oleh Kepala Desa Kaliburu dan dilanjutkan dengan beberapa acara lainnya seperti penyerahan atribut dan alat-alat yang digunakan dalam kegiatan PKM. Atribut berupa baju seragam yang diberikan kepada peserta berjumlah 24 buah sesuai jumlah peserta yang direncanakan. Kelompok terbagi dari 2 (dua) dan setiap kelompok berjumlah 10 orang. Selain atribut, dalam kegiatan PKM ini diberikan juga bantuan alat-alat seperti 1 (satu) unit spiner, 2 buah kompor gas 1000 mata/selangnya, 2 buah wajan ukuran 22 kijang, 2 buah spatula.

\section{Pelaksanaan Pelatihan}

Sebelum demontrasi pembuatan abon ikan, nugget ikan dan pancake fish. Terlebih dahulu narasumber mejelaskan tentang teknik kerja dan tahapan-tahapan pelaksanaannya. Proses dan pelaksanaan kegiatan disajikan pada Gambar 3. di bawah ini.

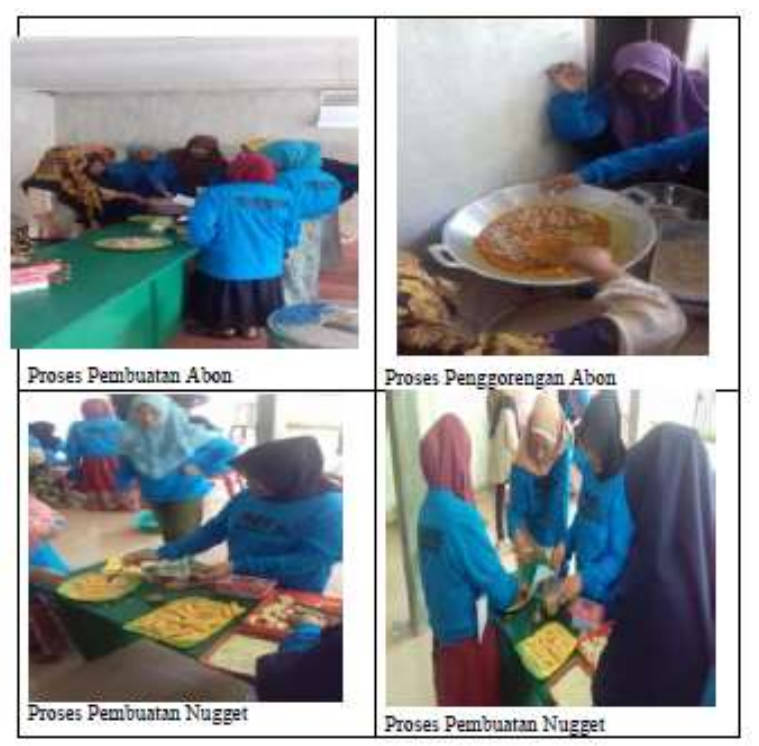

Gambar 3. Proses Pengolahan Ikan

Proses pelatihan dan praktek pembuatan atau pengolahan ikan yang menghasilkan peroduk abon ikan, nugget ikan dan pancake fish. Gambar 3 tersebut di atas adalah proses pengolahan ikan menjadi abon ikan dan nugget ikan. Pengolahan abon ikan bagi perempuan nelayan diharapkan dapat memberi nilai tambah dan sekaligus dapat meningkatkan pendapatan rumahtangga nelayan (Mardjudo dan Asrawaty, 2018). Dalam PKM kali ini selain abon ikan, pengolahan ikan mentah menjadi nugget ikan menjadi suatu yang dapat mendukung pemberdayaan ekomnomi rumahtangga masyarakat, karena minat ibu-ibu untuk mengolah produk tersebut cukup tinggi dan bahkan hasil olahan semua disantap bersama artinya minat peserta merupakan 
representatif menjadi minat masyarakat terhadap produk tersebut cukup tinggi.
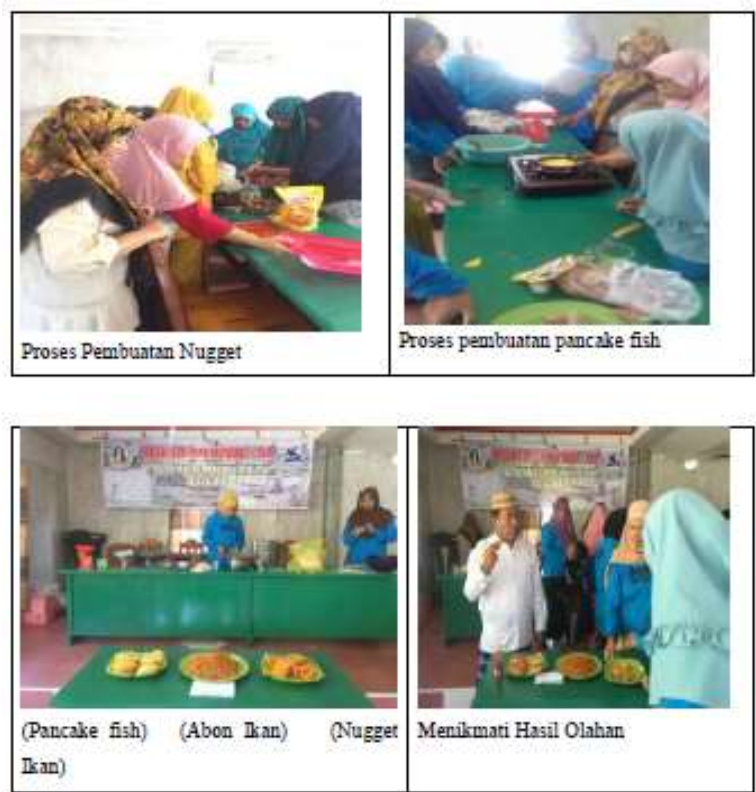

Gambar 4. Proses Pengolahan Pancake Fish

\section{Kesimpulan}

Kegiatan program kemitraan masyarakat (PKM) mendapat respon yang baik dari pemerintah desa Kaliburu dan ibuibu yang menjadi target kegiatan. Kesimpulan dalam kegiatan PKM ini adalah sebagai berikut:

1. Bahwa pemberdayaan perempuan nelayan dalam pelatihan pengolahan hasil perikanan seperti abon ikan, nugget ikan dan pancake fish dapat memberikan nilai tambah bagi masyarakat.

2. Dua kelompok yang sudah dilatih dapat mengolah sendiri produk-produk hasil perikanan, maka dapat dipastikan akan meningkatkan pendapatan rumahtangga mereka.
3. Untuk keberlanjutan progam PKM ini kegiatan pendampingan harus dilakukan baik dari perguruan tinggi yang melakukan pengabdian maupun dukungan penuh dari pemerintah desa setempat.

\section{Ucapan Terima Kasih} kepada;

Ucapan terimakasih disampaikan

1. Direktorat Riset dan Pengabdian Masyarakat Direktorat Jenderal Penguatan dan Pengembangan Kementrian Riset, Teknologi dan Pendidikan Tinggi Republik Indonesia.

2. Lembaga Layanan Pendidikan Tinggi (LLDikti) Wilayah IX Sulawesi Makassar serta

3. Rektor Universitas Alkhairaat Palu, Ketua LPPM Unisa dan Dekan Fakultas Perikanan Universitas Alkhairaat.

\section{Daftar Pustaka}

BPS, 2014. Kecamatan Sindue Tombusabora Dalam Angka. Badan Pusat Statistik Kabupaten Donggala.

BPS, 2015. Kabupaten Donggala Dalam Angka. Badan Pusat Statistik Kabupaten Donggala.

Mardjudo A., dan Asrawaty., 2019. Pemberdayaan Masyarakat Berbasis Potensi Lokal Menuju Desa mandiri di Kecamatan Sindue Tombusabora. Jurnal Inovatif Pengabdian Masyarakat, Edisi Juli 2019.

Muhammad S., 2012. Pemberdayaan Masyarakat Pesisir, Model Kemitraan SocioEcocentrisme. UB Press Malang. 